\title{
STRATEGI BERTAHAN HIDUP NELAYAN P. RIMAU BALAK DI KABUPATEN LAMPUNG SELATAN
}

\section{THE SURVIVAL LIFE STRATEGIC OF THE FISHERMEN COMMUNITY IN RIMAU BALAK ISLAND SOUTH LAMPUNG REGENCIES}

\author{
Sudiyono \\ Pusat Penelitian Kemasyaratan dan Kebudayaan LIPI \\ Jalan Gatot Subroto 10 Jakarta Selatan \\ Email: sudiyono.suwito@gmail.com \\ Dikirim: 14 Maret 2015 Direvisi: 15 Mei 2015 Disetujui: 5 Agustus 2015
}

\begin{abstract}
Abstrak
Masyarakat nelayan P. Rimau Balak di Kabupaten Lampung Selatan, merupakan salah satu kelompok masyarakat yang hidup dalam kondisi miskin. Ada dua faktor yang menyebabkan kemiskinan, yakni; faktor yang bersifat alamiah, dan yang bersifat non-alamiah atau faktor struktural. Faktor alamiah meliputi, degradasi lingkungan perairan, cuaca yang tidak menentu dan perubahan iklim, serta kondisi tangkap lebih (over fishing). Faktor yang bersifat struktural meliputi, sedang faktor struktural meliputi; terbatasnya akses modal, terbatasnya teknologi alat tangkap, kebijakan pemerintah, dan ketidakadilan dalam lembaga sistem bagi hasil. Studi ini bertujuan ingin menjelaskan bagaimana kommunitas masyarakat nelayan P. Rimau Balak dapat bertahan hidup. Sumber data diperoleh melalui wawancara mendalam, pengumpulan dokumen, observasi, dan buku-buku literatur. Hasil penelitian menunjukkan bahwa secara vertikal nelayan memiliki hubungan baik dengan pihak yang menguasai sumber ekonomi, melibatkan keluarga dalam mencari nafkah, serta menghemat pengeluaran. Kemiskinan nelayan bersifat multi-dimensi, sehingga penanganannya tidak secara tambal sulam.
\end{abstract}

Kata Kunci : Strategi Bertahan Hidup, Nelayan, P. Rimau Balak

\begin{abstract}
The fishermen community in Rimau Balak island South Lampung Regencies, is one of the fisherman community which lifing in poverty condition. There are two factors that coused of poverty, namely; natural and non-natural or structural factor. The natural factor are weather uncertinity and climate change, degradation of sea resource and over fishing condition. The factor structural are, low of education and unskill of the fisherman community, limitation of the access of capital, limitation of the technology fishing gear, the gouvermen policy, and unequity institutions sharing sistem. This study aims to exsplain how the fishermen community in Rimau Balak island can be survival life? This article has been written by descriptive qualitatif aproach. Source of data obtained trough indepth interview, document colection, observation, and books litterature. This article is a byproduct of the Coral Reef Rehabilitation and Management Program (COREMAP) survey, that has been done by Population Research Center in Indonesia Institute of Sciences (P2K - LIPI) on Aprill 22 - 30 - 2015.
\end{abstract}

Keywords: Survival Life Strategic, Fishermen, Rimau Balak Island

\section{PENDAHULUAN}

Indonesia dikenal sebagai negara kepulauan. Status negara kepulauan ini dikukuhkan melalui konvensi internasional UNCLOS tahun 1982. Wilayahnya meliputi sejumlah 17.054 pulau yang tersebar dari Sabang sampai Merauke. Panjang garis pantainya $104.000 \mathrm{~km}$, terpanjang ke dua di dunia setelah Kanada. Total luas wilayahnya mencapai 3,544 km2. Panjang garis pantainya mencapai 81.791 $\mathrm{km}$, yang mungkin terpanjang di seluruh dunia. (Supriharyono, 2000,1) Di dalamnya tersimpan potensi kekayaan ikan yang sangat besar, meliputi potensi perikanan tangkap, budidaya, perairan umum, dan lainnya. Potensi tersebut bila dikelola secara optimal, diperkirakan nilainya mencapai US\$ 82 miliar per tahun (http://ernianusamale/11b.studen.itb.ac.id/tag/potensi -perikanan-dan-kelautan-indonesia). Kendatipun demikian, kekayaan sumber daya alam yang melimpah tersebut belum mampu menjamin kesejahteraan masyarakat nelayan yang tinggal di wilayah pesisir pantai. Bahkan lebih menyedihkan lagi kelompok ini termasuk dalam kelompok masyarakat termiskin di bandingkan dengan kelompok masyarakat miskin lainnya (Mubyarto; 1984, 155) 
Masyarakat nelayan P. Rimau Balak, merupakan salah satu dari kelompok nelayan yang masih hidup dalam kubangan kemiskinan. Tanpa harus menghadirkan indikator-indikator yang berupa sederet kriteria kemiskinan pun, sesungguhnya fenomena kemiskinan masyarakat nelayan sudah dapat diketahui secara kasat mata. Sebagian besar rumah-rumah penduduk berbentuk rumah panggung yang terbuat dari bahan material yang berkualitas rendah. Bahan-bahan bangunan ini diperoleh dari lingkungan sekitar tempat tionggal mereka. Dindingnya terbuat dari anyaman bambu (gedeg), tiang-tiang rumah dari kayu-kayu berkualitas rendah seperti kayu sengon. Atap rumahnya terbuat dari bahan daun rumbia. Dari kejauhan rumah-rumah penduduk ini tampak menghitam kusam. Konstruksinya pun tampak tidak kokoh, banyak yang sudah reyot karena termakan usia. Sebagian yang lain, berupa rumah semi permanen. Setengah dindingnya dibangun dari bata merah atau batako, beratap seng atau genteng, berlantai tanah dan ada juga sebagian yang sudah diplester.

Rumah-rumah penduduk ini dilengkapi dengan sarana penerangan yang minim. Aliran listrik ini berasal dari tenaga surya, tetapi karena kurang perawatan aliran listriknya kecil. Ada juga aliran listrik dari genset milik tetangga dekat, tetapi kapasitasnya rendah hanya lima watt. Itu pun nyalanya hanya singkat mulai dari jam 18.000-21.00 malam. Selebihnya gelap gulita, dan sangat jarang ditemukan media komunikasi radio ataupun TV. Rumah-rumah penduduk ini tidak tertata, letaknya berhimpit-himpitan. Di sana sini banyak terdapat jemuran bergelantungan, limbah domestik cair dan padat berserakan di tepi pantai, rumah-rumah penduduk tidak dilengkapi dengan MCK, mereka biasa membuang hajat besar di tepi pantai. Demikian juga biasa membuang sampah di laut. Kebiasaan hidup bersih dan sehat, tampaknya belum menjadi bagian dari hidup mereka. Di tengah-tengah permukiman penduduk Kampung Busung Berah terdapat sarana ibadah Masjid satu-satunya di Dusun Rimau. Jangan dibayangkan bangunan masjid ini sama dengan masjid-masjid lainnya di kota-kota sekitarnya seperti di Bakauheni, Kalianda, Merak, Tangerang, dan Jakarta yang serba besar dan mengkilat, dengan sarana ibadah gelaran permadani yang lembut. Masjid di Dusun Rimau hanyalah berupa bangunan sederhana yang kecil berukuran sekitar 4 x 5 m, temboknya tidak diplester, kondisinya sudah retak-retak, tampak tua dan kotor. Di dalamnya terdapat gelaran tikar yang sudah lusuh. Ada sebuah loud speaker, nyala kelip-kelip, hanya bunyi kresek-kresek sehingga tidak dapat digunakan untuk mengalunkan suara adzan oleh petugas marbot Masjid. Masjid ini juga tampak sepi, sangat jarang warga yang melaksanakan sholat berjamaah, kecuali hanya pada hari Jumat untuk Jumatan. Itupun yang hadir hanya lima orang, tiga orang dari warga dan dua dari peneliti. Lebih miris lagi yang hadir
Jumatan itu, hanyalah orang-orang yang sudah tergolong usia lanjut.

Fenomena penampakkan fisik kemiskinan lainnya adalah alat tangkap dan sarana tangkap yang digunakan tergolong masih sederhana. Jenis alat tangkap yang digunakan berupa pancing tunggal, pancing rawai, dan jaring karang. Sarana tangkap yang digunakan berupa perahu dayung yang sudah dimodifikasi dengan memasang mesin ketinting berukuran 5,5 PK. Masyarakat setempat lazim menyebut perahu ini dengan nama "perahu katir". Dengan teknologi alat tangkap yang masih sederhana, daya jelajah yang terbatas, status wilayah peraiaran yang sudah berada pada tangkap lebih (over fishing), tingkat pencemaran perairan yang tinggi, kesemuanya telah berkontribusi terhadap rendahnya tingkat pendapatan nelayan.

Hasil wawancara dengan Sanusi (35) salah seorang nelayan "kaskow"1 yang merangkap sebagai salah seorang tokoh masyarakat setempat, menuturkan bahwa umumnya masyarakat nelayan di sini adalah nelayan perahu katir, dengan sasaran tangkap utama jenis ikan pelagis seperti kembung, tembang, kuniran, ekor kuning, dan lemuru. Ikan tersebut merupakan jenis ikan yang memiliki nilai ekonomi rendah. Rata-rata harga ikan tersebut pada kisaran antara Rp 10.000,- - Rp 15.000,- per kg. Dalam satu bulan efektif melaut, terhitung 12 kali yang mendapatkan hasil kurang lebih $7 \mathrm{~kg}$ sekali melaut, maka akan diperoleh $84 \mathrm{~kg}$ setara dengan Rp 840.000,-. Angka ini masih harus dikurangi dengan biaya operasional melaut sebesar Rp 360.000,-. Pendapatan nelayan dalam satu bulan sekitar Rp 480.000,- perhitungan ini belum termasuk dengan resiko kegagalan melaut dan resiko kerusakan serta kehilangan alat tangkap, yang sewaktu-waktu menimpa nelayan. Bila diperhitungkan dengan standard kebutuhan fisik minimum pangan sebesar $2100 \mathrm{Kkal}$ dan kebutuhan dasar non pangan, seperti sandang, papan, kesehatan, dan pendidikan setara pemenuhan kebutuhan fisik minimum Rp 211,276,- ( BPS, 2010), hanya cukup untuk memenuhi kebutuhan fisik minimum dua orang. Bila dihitung dengan ukuran World Bank (2005) dengan penghasilan per kapita per hari 2 US\$ kurs dolar diperhitungkan Rp 8500,-, maka dalam hitungan satu bulan pengeluaran per orang untuk memenuhi kebutuhan fisik minimumnya $\mathrm{Rp}$ 510.000,-. Bila kurs dolar dihitung dalam kondisi sekarang (2015) berada pada kisaran Rp 13.000, maka pendapatan nelayan tersebut masih jauh berada di bawah garis kemiskinan. Dalam situasi demikian, menarik untuk dipertanyakan strategi bertahan hidup seperti apa yang mereka lakukan?

\footnotetext{
${ }^{1}$ Kaskow adalah jenis perahu nelayan yang tergolopng besar, berukuran panjang sekitar $9 \mathrm{~m}$, lebar sekitar 1,5 m, ketinggian lambung sekitar $75 \mathrm{~cm}$, dengan mesin dalam berukuran 22 PK, bermesin diesel Dongfeng. Kapasitas antara $10-15$ orang penumpang.
} 
Terminologi strategi dalam tulisan ini mengacu pada definisi yang diajukan oleh Bagong Suyanto dan Karanji; 2005, 62) yakni suatu cara mendapatkan keuntungan atau tujuan. Dalam kaitan dengan tulisan ini adalah strategi nelayan miskin untuk dapat bertahan hidup utamanya dalam memenuhi kebutuhan dasar. Untuk membahas strategi bertahan hidup pada masyarakat nelayan P. Rimau Balak, akan digunakan teori startegi subsistensi petani sebagaimana yang diteorikan oleh J. C. Scott $(1976,167)$ dalam Moral Ekonomi Petani. Kelompok petani miskin dalam menjalankan aktivitasnya selalu dihadapkan dengan resiko. Antara lain penurunan produksi dan kegagalan panen selalu mengancam setiap saat. Penyebabnya macammacam, kekeringan, serangan hama yang terus menerus, banjir, dan bencana alam lainnya. Berbagai strategi bertahan hidup dilakukan oleh petani, antara lain menjalin relasi sosial, strategi nafkah ganda dengan mengoptimalkan seluruh tenaga kerja keluarga, dan melakukan penghematan atau lazim disebut dengan istilah "mengencangkan ikat pinggang”. Startegi yang sama dilakukan oleh kelompok nelayan miskin (Kusnadi;2002, 205)

Dalam menjalin relasi sosial, ini dapat bersifat horizontal dan vertikal. Bersifat horisontal dilakukan dengan mempererat hubungan kekerabatan, kekeluargaan, ketetanggaan, dan pertemanan. Yang bersifat fertikal menjalin hubungan sosial dengan kelompok masyarakat yang memiliki status sosial ekonomi yang lebih tinggi. Sebagian besar kelompok petani miskin yang terbatas kepemilikan sumber daya ekonomi menjalin dengan sekelompok kecil petani yang tergolong kaya yang memiliki kelebihan sumber daya ekonomi. Sumber daya ekonomi ini bisa berujud pemilikan tanah luas, kepemilikan modal, dan kepemilikan terhadap akses sumber daya ekonomi lainnya seperti lembaga keuangan yang sah. Hubungan yang timpang ini telah melahirkan apa yang disebut sebagai hubungan yang bersifat patronclient.

Corak hubungan sosial patron - client, sudah barang tentu tidak semata-mata ditentukan oleh ikatan ekonoimi, tetapi juga ditandai oleh ikatan emosiaonal antara sang patron sebagai pelindung dan client sebagai anak buah. Di Indonesia hubungan seperti ini lazim disebut sebagai "hubungan bapak anak buah" atau "bapakisme/paternalisme) (Yahya Muhaimin, 1980; 22). Dalam sistem bapakisme ini, "Bapak" (patron) dipandang sebagai tumpuan dan sumber pemenuhan kebutuhan material bahkan spiritual, serta pelepasan kebutuhan emosional "anak buah” (client), sebaliknya anak buah dijadikan sebagai tulang punggung yang setia dalam menjalankan bisnisnya. Hubungan sosial seperti itu merupakan hubungan timbal balik untuk saling memberi dan menerima. Hubungan seperti itu terjadi secara informal antara dua fihak yang masingmasing mempunyai status yang tidak sama tinggi derajatnya. Dalam hubungan seperti itu, sulit diketahui siapa memanfaatkan siapa, sebab ke dua belah pihak memperoleh sesuatu yang diharapkan masing-masing, walaupun tidak sepadan. Di pedesaan hubungan seperti itu lebih kuat dibandingkan dengan di perkotaan. Di desa lebih sedikit patron, dibanding di kota sehingga seseorang menemukan banyak alternatif mencari sang patron. Di pedesaan, fakta hubungan "hutang budi", masih lebih kuat, melalui prinsip "malu”, “segan”, "sindiran”, “tenggang rasa”, "hormat bapak”, "hutang budi”, menurut kajian Karl D. Jackson \& Lucian W. Pye (1978; 375) sangat mengagumkan sekali halusnya.

Kendatipun demikian, harus diakui bahwa unsur ekonomi memang sangat menentukan. Bila kebutuhan subsistensi petani miskin masih bisa diselamatkan dengan bantuan dari Sang patron, maka hubungan tersebut akan terjamin tetap langgeng, tetapi bila kebutuhan subsistensi petani tidak dapat dipenuhi lagi, maka hal ini akan mengancam kelangsungan hubungan patron - client. Bagi Scott yang melakukan pendekatan "moral ekonomic" menandai bahwa kehidupan masyarakat "peisanpedesaan” dalam memenuhi kebutuhan subsistensinya dipandu oleh dua prinsip utama yaitu, the norm of reciprocity (adat tolong menolong) dan the right to subsistence (hak untuk hidup pada paras subsistens). Kekuatan dan keberlanjutan dari ke dua prinsip moral ini tergantung pada ketentuan moral penduduk dalam menyatakan sikap setuju atau tidak setuju dalam menghadapi perubahan. Bila ada intervensi dari luar, atau alternatif lain pekerjaan di luar hubungan kerja yang telah ada, maka hubungan tersebut besar kemungkinan akan berdampak pada melemahnya hubungan patron - client (Scott; 1976, 167)

Dari sudut pandang petani sendiri (emic), hubungan tersebut tidak ada masalah dan tidak ada sama sekali unsur negatifnya, karena tidak ada pihak yang dirugikan. Pandangan seperti ini dapat dimengerti, ditengah kelangkaan sumber daya yang dimiliki, dan ketiadaan pihak lain yang dapat mengatasi kebutuhan subsistensi petani, maka Sang patron akan dianggap sebagai dewa penyelamat. Hal ini berbeda dengan pandangan orang luar (etic) yang melihat bahwa hubungan ini dapat mengarah pada tindakan eksploitatif yang dapat menjerat petani pada kubangan kemiskinan. Terlepas dari perbedaan sudut pandang tersebut, realitas petani miskin dengan segala keterbatasan dalam memenuhi kebutuhan subsistensinya, telah menempatkan sang patron sebagai gantungan hidup satu-satunya.

Pertanyaan menarik kemudian adalah, apakah teori tersebut dapat digunakan untuk menjelaskan strategi kelompok nelayan miskin dalam memenuhi kebutuhan subsistensinya. Bila mengamati resiko yang dihadapi nelayan dalam menjalankan aktivitasnya, tampaknya tingkat resiko yang dihadapi nelayan justru lebih tinggi dibandingkan dengan resiko yang dihadapi petani. Gagal melaut dengan 
tidak memperoleh hasil tangkapan, dengan resiko pengurbanan materi dan tenaga, hal yang biasa dihadapi nelayan. Kegiatan nelayan berlangsung dalam suatu lingkungan heterogen dan tidak menentu (uncertain). Ketidaktentuan ini berakar tidak hanya pada kondisi lingkungan fisik, tetapi juga lingkungan sosial di mana kegiatan nelayan berlangsung. Seperti diketahui, laut adalah suatu lingkungan yang berbahaya, suatu lingkungan di mana secara fisik alami, manusia dibekali kemampuan yang amat terbatas untuk dapat hidup di atasnya. Laut juga dihuni oleh banyak species mahluk hidup dengan ukuran, kebiasaan dan tempat hidup yang berbeda. Ikan merupakan salah satu contoh sumber daya laut yang cukup sulit untuk dieksploitasi. Kesulitan ini lahir bukan hanya karena ikan-ikan itu bermigrasi secara musiman, tetapi juga populasi ikan dapat naik dan turun secara drastis, kondisi tersebut sulit diprediksi, bahkan oleh para ahli perikanan sekalipun (Acheson, 1981, 276)

Ketidaktentuan lingkungan sosial juga dihadapi oleh nelayan. Keberhasilan kegiatan menangkap ikan belum tentu pula menjamin pendapatan yang memadai. Banyak kajian menunjukkan tingkat fluktuasi harga ikan di pasar begitu tinggi dan sangat sulit diramalkan. Kesulitan lain dalam pemasaran hasil tangkapan juga lahir dari keterbatasan nelayan untuk bisa mengikuti mekanisme pasar. Hal ini karena nelayan tidak berada di darat, dan aktivitas melaut acap kali tidak sesuai dengan kegiatan pasar, sehingga nelayan tidak memiliki akses informasi pasar. Informasi pasar, bahkan pasar itu sendiri sangat ditentukan oleh para pemilik modal yang sering merangkap sebagai pedagang pengumpul ikan (Acheson, 1981, 282).

Dengan kata lain kegiatan nelayan mulai dari tingkat produksi dan distribusi pemasaran dihadapkan pada berbagai persoalan yang diakibatkan oleh ciri dari ketidakpastian lingkungan. Menghadapi kondisi demikian nelayan mengadakan berbagai respon berupa berbagai macam penyesuaian guna menekan resiko ketidakpastian. Salah satu respon nelayan yang cukup penting bagi nelayan yang tergolong mampu adalah melakukan pemanfaatan teknologi. Kalau demikian, bagaimana halnya dengan nelayan miskin yang tidak memiliki kemampuan untuk mengubah teknologi alat tangkapnya. Jangankan mengubah alat tangkapnya, untuk mempertahankan alat tangkap yang ada pun nelayan masih mengalami kesulitan. Seperti diketahui nelayan dalam menjalankan aktivitasnya dihadapkan dengan resiko kerusakan alat tangkap, perahu yang digunakan, dan peristiwa alam yang dapat mengancam keselamatan jiwanya, yang sewaktu-waktu dapat terjadi. (Aceson, 1981, 278 279) Kerusakan itu harus segera diperbaiki, dan untuk memperbaikinya membutuhkan biaya yang tidak sedikit. Persoalan muncul pada saat nelayan harus pergi melaut, pada saat yang sama nelayan tidak memiliki uang tunai untuk memperbaiki dan memenuhi kebutuhan bekal melaut, sementara pemenuhan kebutuhan hidupnya pasti dan tidak bisa ditunda. Dalam menghadapi situasi demikian, nelayan melakukan strategi bertahan hidup yang kurang lebih sama sebagaimana halnya yang dilakukan oleh kelompok petani miskin.

Sebelum pembahasan lebih lanjut mengenai strategi bertahan hidup nelayan P. Rimau Balak, akan diuraikan terlebih dahulu mengenai kondisi P. Rimau Balak dan sejarah permukiman penduduk. Uraian ini penting karena menyangkut identitas suatu kelompok masyarakat agar dalam penyebutan nama dusun dan pulau tidak terjadi kesalahan. Mengacu pada Konvensi PBB No: 4 tahun 2004, pembakuan nama rupa bumi harus memperhatikan aspirasi masyarakat yang mendiami kawasan tersebut. Selain itu, peraturan Presiden RI Nomor 112 tahun 2006, juga mensyaratkan hal yang sama. Temuan di lapangan menunjukkan bahwa masyarakat merasa asing karena tidak terbiasa mendengar penyebutan nama "Pulau Rimau Balak". Masyarakat bertanyatanya, siapa yang memberi nama pulau ini dengan nama P. Rimau Balak ? Dalam percakapan keseharian, masyarakat lazim menyebutnya pulau ini dengan nama Pulau Rimau. Antara Dusun Rimau dengan P. Rimau memiliki sejarah tersendiri yang ke duanya tidak dapat dipisahkan. Kendatipun demikian, penyebutan P. Rimau Balak sudah terlanjur banyak digunakan orang dan dimuat dalam laporan-laporan resmi dalam administrasi pemerintah, beredar di media sosial, laporan hasil penelitian, sehingga orang luar lazim menyebut $\mathrm{P}$. Rimau Balak

\section{METODE}

Tulisan ini merupakan sisi lain dari temuan hasil penelitian Survey Coral Reef Rehabilitation and Management Program (COREMAP) yang dilakukan oleh Pusat Kajian Kependudukan (P2K - LIPI) yang berlangsung dari tanggal 22 - 30 April 2015. Dalam survey tersebut penulis ikut terlibat aktif melakukan kegiatan penelitian, baik yang bersifat kuantitatif maupun kualitatif. Penelitian kualitatif dilakukan dengan pengamatan langsung di lapangan, wawancara mendalam kepada sejumlah nelayan dan tokoh masyarakat, wawancara melalui Focus Group Discution (FGD), sertra pengumpulan data sekunder di beberapa instansi pemerintah terkait.

\section{HASIL DAN PEMBAHASAN}

\section{Sejarah Permukiman dan Kondisi P Rimau Balak}

P. Rimau Balak merupakan salah satu pulau yang berpenghuni di antara pualu di wilayah gugusan kepulauan perairan Selat Sunda, Kabupaten Lampung Selatan. Luas pulau ini mencapai 500 ha. Pulau ini dikelilingi oleh beberapa pulau yang tidak berpenghuni; antara lain, P. Kandang Balak, P. 
Panjurit, P. Keramat, dan P. Sekepel. Secara administratif P Rimau Balak berada pada wilayah Desa Sumur, Kecamatan Ketapang, Kabupaten Lampung Selatan. Secara geografis posisi P. Rimau Balak sangat strategis, berada di tengah perlintasan penyeberangan Kapal Fery Roro Merak-Bakauheni. Untuk mencapai P. Rimau Balak, dari arah Pelabuhan Bakauheni naik sedikit sampai di pertigaan Sieker, belok kanan ambil jalan trans timur Sumatra kurang lebih $3 \mathrm{~km}$, belok kanan menyusuri jalan kampung sekitar $1 \mathrm{~km}$, sampailah di Pelabuhan Pendaratan Ikan (PPI) Dusun Keramat. Dari PPI Dusun Keramat naik perahu ketinting sekitar 30 menit ke arah timur menyusuri perairan Selat Sunda sampailah di Dermaga Kampung Busung Berah. Dari kejauhan P. Rimau Balak berupa gunung berapi yang menyembul di permukaan air laut. Ketinggian dari permukaan air laut $212 \mathrm{~m}$. Pada kaki-kaki bukit yang landai terdapat beberapa kelompok permukiman penduduk, antara lain di sebelah barat daya, tenggara, timur laut, dan barat laut. Untuk sebuah pulau yang tergolong kecil, pulau ini termasuk pulau yang berpenduduk padat. (http://fdwiagungwidodo.wordpress.com).

Secara ekologis P. Rimau Balak memiliki beberapa ekosistem, antara lain ekosistem mangrove berada pada pantai bagian tenggara, selatan, barat daya, dan barat laut. P. Rimau Balak juga dikelilingi oleh ekosistem padang lamun dan terumbu karang pada kedalaman antara $1 \mathrm{~m}-16 \mathrm{~m}$. Berbagai vegetasi yang tumbuh di P. Rimau Balak antara lain; waru laut (hibiscus tilaceas), putat laut (baringtona sp), ketapang (terminalia cattapa), hutan mangrove seperti bakau (rhizoppora sp), nypah (nypah frutilae), dan bogem (sonneratia $s p$ ) (http://fdwiagungwidodo.wordpress.com)

Kondisi perairan sekitar P. Rimau Balak sudah mengalami kerusakan ekosistem yang berdampak pada penurunan daya dukung lingkungan. Hasil kajian Aldilla, 2014 menemukan tutupan karang hidup di P. Rimau Balak, Kandang Balak, dan Panjurit berkisar 11\% sampai 63\%, karang mati $6 \%$ sampai $49 \%$, karang lunak $10 \%$ sampai 48,7\%, dan alga 1\% sampai 35\%. Menurut Zamani dan Padupa (2012), sebagaimana dikutip Aldilla, disebutkan bahwa kriteria untuk kesehatan terumbu karang yang masuk pada kategori pulaupulau kecil harus memiliki tutupan karang hidup berkitar $75 \%$ sampai $100 \%$, dan alga $1 \%$ sampai $36 \%$, sehingga dapat dikatakan bahwa perairan P. Rimau Balak, P. Kandang Balak, dan Panjurit berada dalam kondisi buruk menuju sedang. Temuan lainnya keragaman jenis terumbu karang mengalami penurunan, dan banyak ditemukan kematian karang. Penyebabnya karena menurunnya kualitas air baik secara fisika, kimia, dan biologi. Didalamnya terkandung zat pencemar berupa bahan organik, nitrogen, posfat dan logam (Pb) (http://respository/ipb.ac.id/handle/123456789/70324
Adapun beberapa sumber pencemar tersebut berasal dari limbah padat dan cair dari rumah tangga, pencemaran minyak dari padatnya aktivitas penyeberangan kapal Roll on-Roll off atau kapal Roro (Fery) Merak-Bakauheni, limbah cair pencucian kapal, limbah kimia budi daya pertanian dan tambak, dan limbah buangan aktivitas industri. Sumber lain menyebutkan bahwa Indikasi telah terjadinya tingkat pencemaran yang tinggi adalah munculnya fenomena alam "red tide" yang melanda perairan Teluk Lampung yang berdampak pada kematian ikan secara masal pada ikan kerapu dalam keramba yang dibudidayakan nelayan, peristiwa ini terjadi hampir setiap tahun (Kompas. 6 Juni 2013)

Sumber pencemaran perairan Selat Sunda juga diduga berasal dari limbah kimia pertanian. Menurut informasi dari Totok, pertanian monokulture tanaman pangan jagung dalam areal seluas 1 ha per tahun, dibutuhkan pupuk kimia sebesar 8 kuwintal, dan obat penyemprot hama sebesar 15 liter. Bahan kimia obat-obatan tersebut bermerek Rundup, Rodiamin, Kalaris, dan Kramson. Pada musim penghujan larutan kimia bersama erosi tanah akan terbawa dan masuk ke laut (Wawancara dengan Totok di Dusun Pegantungan 24 April 2015)

Perairan pantai Selat Sunda juga sudah mengalami tingkat sedimentasi yang tinggi, yang disebabkan oleh berbagai aktivitas pertanian dan pembangunan. Berkembangnya tanaman monokultur jagung untuk pakan ternak telah mengubah perbukitan di lampung menjadi gundul. Perbukitan yang sebelumnya banyak ditumbuhi tanaman keras dan belukar, dikupas untuk pengembangan tanaman jagung. Di musim kemarau perbukitan tampak memerah dan gersang. Hilangnya tutupan bukit dari tanaman keras pelindung, telah berdampak pada terjadinya erosi tanah pada setiap musim penghujan. Sedimentasi juga ditengarai berasal dari aktivitas reklamasi pantai untuk berbagai keperluan sepereti membangun jalan tol lintas Bakauheni-Palembang, penambahan bangunan dermaga Pelabuhan Bakauheni, pembangunan Pelabuhan Umum Rakyat oleh PT. Bandara Jaya,, penambangan pasir, penempatan industri pencetakan tiang beton milik PT. Wijaya Karya, pembangunan hotel, industri, dan perluasan permukiman penduduk, seolah semua berlomba mencari lokasi tapak bangunan di seputar pantai Pelabuhan Bakauheni. Berbagai aktivitas penangkapan ikan yang bersifat destruktif yang dilakukan pada masa lalu dengan kegiatan pemboman dan penggunaan potasium, serta aktivitas pengambilan batu karang untuk berbagai keperluan, juga telah meninggalkan sisa-sisa kerusakan terumbu karang yang dampaknya dapat dirasakan langsung oleh masyarakat nelayan yakni semakin sulitnya mencari ikan di sekitar perairan pantai.

Dahulu wilayah P. Rimau Balak merupakan areal berkebun penduduk asli Lampung yang tinggal di wilayah seberang Desa Sumur, Kecamatan 
Ketapang. ${ }^{2}$ Untuk menjaga kebun dan beristirahat saat bekerja di kebun, penduduk membangun pondok-pondok darurat. Menurut informasi Suminto Kadus Dusun Keramat, Dusun Rimau termasuk dusun tua di Desa Sumur. Kendatipun hanya berujud pondok-pondok kebun, tetapi aktivitas masyarakat pekebun dalam kesehariannya, terutama di siang hari, tidak jauh berbeda dengan penduduk yang bermukim di perkampungan. Mereka memasak, mencuci, menyimpan alat-alat pertanian, memperbaiki alat-alat pertanian, membuat perahu, menyimpan dayung, dan melabuhkan perahu di tepi pantai. Pada masa pemerintahan Orde Baru tepatnya pada tahun 1990-an awal, P. Rimau Balak diprogramkan menjadi daerah tujuan wisata, dan lokasi perjudian.

Untuk merealisasikan program tersebut, telah dibangun landasan hellly, dan bangunan-bangunan yang kondisinya baru setengah jadi. Hadirnya para pekerja bangunan, turut meramaikan aktivitas di $\mathrm{P}$. Rimau Balak. Para pekerja tersebut juga membangun rumah-rumah bedeng sementara di P. Rimau Balak. Dampak langsung dari program tersebut adalah hadirnya para spekulan tanah. Masyarakat setempat menduga bahwa mereka itu adalah para kroni Soeharto. Jatuhnya rezim pemerintahan Orde Baru, membuat program tersebut terhenti, dan beberapa sisa bangunan yang ada rusak terbengkelai. Namun demikian masyarakat penghuni P. Rimau Balak sudah terlanjur ramai saat itu. Disusul dengan krisis ekonomi yang melanda bangsa Indonesia, justru membawa akibat penghuni P. Rimau Balak bertambah banyak. Mereka datang dari berbagai wilayah dengan latar belakang etnik dan sosial ekonomi yang berbeda, ada dari Jawa, Lampung, Bugis, Sunda, dan Betawi. Latarbelakang pekerjaan mereka juga bermacam-macam ada yang dari petani, mantan sopir bus angkutan kota di Jakarta, mantan tukang becak, karyawan kurban PHK, dan orangorang Bugis yang sudah tidak sanggup melaut lagi karena usia. Ada juga yang berasal dari buruh tani atau petani tak bertanah, umumnya adalah penduduk asli dari Lampung dan Banten. Mereka membangun rumah tinggal di tepi-tepi pantai P. Rimau Balak yang kemudian berkembang menjadi permukiman penduduk Dusun Rimau yang sekarang. (Wawancara dengan Suminto, 24 April 2015).

Nama Dusun Rimau, memiliki ceritera mitologinya tersendiri. Menurut penuturan salah seorang tokoh masyarakat diceriterakan bahwa dahulu P. Rimau Balak merupakan tempat berkebun penduduk asli Orang Lampung. Di tepi-tepi pantai penduduk membangun pondok-pondok darurat sebagai tempat istirahat setelah bekerja di kebun. Pondok-pondok ini hanya digunakan sebagai tempat

\footnotetext{
${ }^{2}$ Masyarakat Dusun Rimau menyebut wilayah Pelabuhan Bakauheni dan sekitarnya sebagai wilayah seberang, atau wilayah darat. Bila akan pergi ke Desa Sumur, atau ke Bakauheni, masyarakat lazim mengatakan akan pergi ke darat, atau ke seberang.
}

berteduh dan istirahat di siang hari. Sore harinya, mereka pulang menyeberang laut pulang di kampung mereka yakni Desa Sumur yang sekarang. Suatu hari moyang Jogoniti ketika hendak pulang menyeberang ke kampung Sumur, tiba-tiba melihat dua ekor harimau besar terjepit oleh kima di sebuah tanjung. Hewan tersebut mengerang kesakitan, sambil mendongakkan kepalanya di atas permukaan air laut. Melihat pemandangan seperti itu, segera moyang Jogoniti memberikan pertolongan. Di hadapan ke dua harimau itu, moyang Jogoniti berucap bersedia memberikan pertolongan dengan permintaan kelak jangan mengganggu anak cucu kami. Harimau pun mengangguk seraya berucap menyetujui permintaan moyang tersebut. Kemudian moyang Jogoniti menolongnya ke dua harimau malang itu. Sayang harimau yang jantan tidak terselamatkan, dan hanya yang betina yang berhasil diselamatkan. Setelah lepas dari himpitan kima, harimau betina kemudian berlari pincang pada kaki belakangnya, dan dalam sekejab kemudian menghilang di rimba P. Rimau Balak.

Tempat hewan laut kima bersarang di sebuah tanjung tersebut lazim disebut "Tanjung Pulau Uludan", Tempat ini berada di sebelah barat Kampung Busung Berah, yang sekarang dijadikan sebagai tempat berlabuh perahu-perahu nelayan. Oleh masyarakat tempat ini tidak dikeramatkan, hanya ada pamali yang harus di taati oleh siapapun orang yang hendak menambatkan perahunya atau melewati tempat ini, pantang untuk berkata-kata kasar, berperilaku tidak sopan. Bila pamali ini dilanggar, akibatnya bisa fatal, antara lain jatuh sakit, atau akan menghadapi mara bahaya selama perjalanan di laut. Tempat moyang Orang Lampung membangun pondok-pondok di P. Rimau Balak kemudian diberi nama Dusun Rimau yang sekarang (Wawancara dengan Nurjaman, 25 April 2015) Ceritera mengenai keberadaan harimau penunggu $\mathrm{P}$. Rimau Balak yang penuh misterius ini diyakini oleh masyarakat hingga sekarang.

P. Rimau Balak yang luasnya sekitar 500 ha, terdapat empat kelompok permukiman penduduk, yakni Kampung Busung Berah, terletak di bagian Barat Daya, Kampung Peritaan berada pada sebelah Barat Laut, Kampung Suka Maju di sebelah Tenggara, dan Kampung Buah berada di sebelah Timur. Secara keseluruhan berpenduduk P. Rimau Balak berjumlah 307 jiwa, yang terbagi kedalam 87 KK. Penduduk tersebut tersebar di empat kampung, dengan rincian Kampung Berah 24 KK, Peritaan 34 KK, Buah 7 KK, dan Suka Maju 22 KK. (Wawancara dengan Sanusi 24 April 2015). Sumber lain mencatat bahwa P. Rimau Balak yang kecil dihuni oleh sejumlah $130 \quad$ KK (https:fdwiagungwidodo.wordpress.com) Keempat kampung ini berada di dalam satu wilayah administrasi Dusun Rimau. Seluruh penduduk menjadikan nelayan sebagai matapencaharian utama mereka. 


\section{Karakteristik Nelayan}

Seperti telah disinggung pada uraian sebelumnya, bahwa nelayan P. Rimau Balak merupakan nelayan tradisional yang di tandai oleh berbagai keterbatasan, antara lain rendahnya tingkat pendidikan dan keterampilan, terbatasnya pemilikan modal, terbatasnya akses informasi pasar, tidak terjangkau oleh layanan lembaga keuangan resmi, penggunaan teknologi alat tangkap yang sederhana, yang kesemuanya berujung pada rendahnya tingkat pendapatan. Bertolak dari kondisi nelayan tersebut, Satria (200, 28 - 29) mengklasifikasikan nelayan berdasarkan kapasitas teknologi, orientasi pasar, serta karakteristik nelayan pada corak hubungan sosial kedalam beberapa tingkatan, yaitu: peasant fisher, post peasant fisher, commercial fisher, dan industrial fisher.

(1).Peasant Fisher, merupakan nelayan yang masih berorientasi pada pemenuhan kebutuhan sendiri. Peasant Fisher dicirikan oleh penggunaan teknologi alat tangkap yang masih sederhana, ukuran perahunya kecil, daya jelajah dan daya muat terbatas, besaran modal usaha terbatas, jumlah anggota penangkapan kecil, pembagian kerja berlangsung secara kolektif, serta mengutamakan nilai-nilai kekeluargaan dan kekerabatan.

(2)Post Peasant, merupakan nelayan yang lahir setelah terjadi modernisasi perikanan tangkap. Nelayan Post Peasant dicirikan oleh penggunaan teknologi alat tangkap yang lebih maju, berorientasi pasar, serta tidak lagi menggunakan tenaga kerja keluarga.

(3)Commercial Fisher, merupakan nelayan yang berorientasi pada peningkatan keuntungan. Commercial fisher, dicirikan oleh banyaknya jumlah tenaga kerja yang digunakan, diferensiasi status awak kapal yang berbeda-beda karena teknologi alat tangkap yang digunakan membutuhkan spesialisasi dalam pengoperasiannya.

(4)Industrial fisher, ditandai oleh pengorganisasian proses produksi yang padat modal, dengan manajemen yang mirip seperti perusahaan agroindustri. Pendapatan yang dihasilkan jauh lebih tinggi, karena produk yang dihasilkan adalah ikan kaleng dan ikan baku untuk eksport.

Sementara itu, Kusnadi (2002, 160) juga mengklasifikasikan nelayan berdasarkan; (1) Penguasaan alat produksi atau alat tangkap, (2) besarnya investasi modal usaha, serta (3) penggunaan teknologi alat tangkapnya. Berdasarkan penguasaan alat produksi, nelayan dapat digolongkan sebagai nelayan pemilik dan buruh nelayan. Berdasarkan investasi usahanya, nelayan dikelompokkan kedalam nelayan besar dan nelayan kecil, dan berdasarkan alat tangkap yang digunakan, nelayan dikelompokkan menjadi nelayan tradisional dan nelayan modern.

Berdasarkan jenis alat tangkap yang digunakan, nelayan P. Rimau Balak tergolong sebagai nelayan tradisional, juga termasuk dalam kategori nelayan kecil, serta nelayan "Peasant Fisher", karena hanya berorientasi peda pemenuhan kebutuhan subsisten. Berdasarkan status kepemilikan alat tangkap, mereka termasuk nelayan pemilik, sekalipun dimiliki dengan cara berhutang. Dalam menjalankan aktivitasnya, nelayan hanya menggunakan sarana berupa perahu katir berkapasitas 2 orang yang telah dilengkapi dengan perahu mesin ketinting berkekuatan 5,5 PK. Daya jelajahnya sangat terbatas hanya berkisar di seputar perairan pantai. Jenis alat tangkap yang digunakan pancing rawai dan jaring karang. Sasaran tangkap utamanya adalah ikan-ikan pelagis seperti, ikan kembung, kuniran, peperek, tudak, tembang, cumi, lemuru, dan belanak. Jenis ikan ini merupakan ikanikan yang memiliki nilai ekonomi rendah yang umumnya menjadi konsumsi rumah tangga. Adapun beberapa wilayah tangkap (fishing ground) mereka meliputi; perairan sekitar Tanjung Tua, P. Sangiang, P. Tempurung, dan P. Sebesi, sedang pengoperasian jaring tudak, meliputi; perairan sekitar P. Panjurit, P. Kandang, P. Sangiang, dan P. Sebuku.

Mereka pergi melaut, pagi sekitar Jam 05.00, dan akan pulang sekitar Jam 12.00 - 14.00 siang. Ada juga yang berangkat, sekitar Jam 13.00 siang, dan akan pulang pada pagi hari sekitar Jam 05.00 pagi. Bila hasilnya banyak, langsung akan dijual kepada pedagang penampung ikan di TPI Dusun Keramat. Bila hasilnya sedikit nelayan akan langsung pulang, dan seluruh hasil tangkapannya hanya akan dikonsumsi sendiri, atau akan dijual kepada nelayan Kaskow. Ikan tersebut oleh nelayan Kaskow akan dimanfaatkan sebagai umpan. Harga di tempat nelayan Kaskow untuk ikan umpan Rp 10.000,-, dan di tempat pengumpul PPI Dusun Keramat Rp 14.000,- per kg. Baik nelayan Katir maupun nelayan Kaskow termasuk dalam kategori nelayan tradisional karena wilayah tangkapnya hanya diseputar perairan pesisir pantai.

Nelayan-nelayan kecil ini dihadapkan pada berbagai permasalahan, antara lain wilayah perairan yang sudah mengalami tangkap lebih (over fishing), kerusakan ekosistem perairan pantai, dan persaingan dengan nelayan yang mengoperasikan alat tangkap ikan yang lebih moderen yang mampu bergerak lebih cepat, mampu mendeteksi kawanan ikan, memiliki daya jelajah yang luas, serta memiliki tingkat eksploitasi yang lebih tinggi. Berlangsungnya fenomena perubahan iklim sebagai dampak pemanasan global, tampaknya juga telah melengkapi permasalahan yang dihadapi nelayan kecil. Beruntung aktivitas penangkapan ikan di perairan Selat Sunda ini tidak terpengaruh oleh musim angin Barat dan Timur. Wilayah perairan dengan gugusan pulau yang betebaran, dapat melindungi wilayah perairan dari hempasan gelombang dan angin laut, sehingga aktivitas penangkapan ikan dapat dilakukan secara bergantian tempat, tergantung kemana angin berhembus. 
Hal yang kurang lebih sama juga dihadapi oleh nelayan P. Rimau Balak. Wilayah perairan Selat Sunda, merupakan suatu kawasan perairan yang padat dengan aktivitas penangkapan ikan. Wilayah perairan ini di datangi oleh nelayan dari berbagai wilayah (nelayan andon), ada dari Pantura, Sibolga, dan Bengkulu. Nelayan ini berebut ikan dengan nelayan setempat (Banten, Serang, Tangerang, dan Lampung). Kepadatan wilayah perairan ini masih ditambah dengan para wisatawan komunitas mancing mania yang datang dari berbagai penjuru kota di sekitarnya.

Diantara aktivitas penangkapan tersebut, salah satu yang dianggap pesaing paling mematikan bagi nelayan perairan Kabupaten Lampung Selatan, termasuk di dalamnya nelayan P. Rimau Balak adalah kehadiran nelayan andon dari Pantura yang mengoperasikan kapal bagan congkel. Perahu bagan congkel ini dilengkapi sejumlah lampu penerang dengan kapasitas yang tinggi, antara 5000 watt 6000 watt. Hal ini berakibat ikan-ikan pelagis di perairan pantai akan tertarik ketengah. Jumlah kapal bagan congkel ini mencapai ratusan. Keberadaannya dapat diketahui saat berlabuh di beberapa pelabuhan pendaratan, seperti di Pelabuhan Bom Kalianda, pelabuhan PPI Muara Pilu, dan PPI Dusun Keramat sendiri. Keberadaan kapal bagan congkel sangat mendominasi dibanding dengan kapal dan perahu nelayan setempat seperti perahu katir dan pursine. Kendatipun demikian, tidak ditemukan data tertulis menyangkut berapa jumlah pastinya kapal bagan congkel tersebut yang beroperasi di wilayah perairan Kabupaten Lampung Selatan. Spesifikasi jenis kapal dan alat tangkap ini secara resmi memang tidak diketemukan dalam daftar jenis alat tangkap ikan yang berada di Kantor Dirjen Perikanan Tangkap. Selain itu, kehadiran mereka juga sering tidak melapor kepada petugas perikanan setempat. (Wawancara dengan, Jajang Kepala UPT PPI Bakauheni 27 April 2015).

Nelayan kapal bagan congkel ini memiliki sasaran tangkap yang sama dengan nelayan setempat, yakni jenis-jenis ikan pelagis, seperti, teri nasi, teri medan, kembung, cumi-cumi, tembang, kuniran, tude, belanak, selar, layur, dan kuek (simba). Akibat langsung yang dirasakan oleh nelayan setempat dengan kehadiran nelayan kapal bagan congkel ini adalah merosotnya hasil tengkap nelayan setempat, matinya nelayan bagan, dan pada ujungnya hancurnya industri pengolahan ikan teri di Kabupaten Lampung Selatan. Di Kalianda, tempat sejumlah industri pengolahan ikan teri nasi dilakukan, kini sudah tidak ditemukan lagi. Yang masih tersisa hanyalah tungku-tungku, pondokpondok tempat istirahat pekerja, bakul-bakul yang berserakan, dan rak-rak bambu tempat menjemur ikan yang sudah rusak. Di pantai banyak ditemukan bagan tancap yang sudah rusak yang tampaknya sudah lama tidak dioperasikan lagi. Di Dusun Pegantungan, Bakauheni, malah sudah tidak diketemukan lagi sisa-sisa aktivitas penangkapan dan pengolahan ikan teri. Menurut informasi Totok, dahulu tahun-tahun 1980 - 1990-an awal, terdapat puluhan jumlah bagan tancap dioperasikan di perairan pantai Dusun Pegantungan yang dioperasikan oleh nelayan Bugis, sekarang sudah tidak ada lagi (Wawancara dengan Totok, Pedagang Penampung Ikan di Dusun Pegantungan 24 April 2015). Di perairan pantai Dusun Keramat hanya tingga 2 bagan tancap yang masih dioperasikan, dan itu pun terancam bangkrut. Lainnya hanya tinggal patok-patok bambu yang menyembul di permukaan air laut yang keberadaannya tersebar di sepanjang perairan pantai.

\section{Hasil Tangkap dan Distribusinya}

Seperti telah disebutkan pada uraian sebelumnya, bahwa nelayan P. Rimau Balak sebagian besar hanya mengoperasikan alat tangkap pancing rawai dan jaring. Mereka beroperasi dengan menggunakan perahu ketinting yang oleh masyarakat setempat lazim disebutnya sebagai perahu katir. Pedrahu ini kapasitasnya sangat terbatas, hanya memuat maksimal 2 orang. Perahu ini digerakkan dengan mesin ketinting berkekuatan 5,5 PK. Ada juga yang mengoperasikan perahu Kaskow, tetapi jumlahnya tidak signifikan, yakni hanya 4 orang. Daya jelajahnya hanya di seputar perairan pantai dengan waktu tempuh kurang lebih 30 menit.

Sasaran tangkapnya adalah ikan-ikan pelagis, terutama ikan kembung. Hanya sesekali kalau nasib sedang mujur dapat juga ikan-ikan besar yang memiliki nilai ekonomi tinggi, seperti ikan kerapu merah (sunu), kerapu macan, tenggiri, kakap merah, dan kuek (simba). Seluruh hasil tangkapan langsung dijual kepada pedagang penampung di PPI Dusun Keramat. Sesampai di PPI Dusun Keramat, "Bos" pedagang pengumpul ikan langsung memilah-milah ikan sesuai dengan besar dan jenisnya. Ikan-ikan kembung dikumpulkan sendiri, demikian juga ikanikan besar yang memiliki nilai ekonomi tinggi, dipilah-pilah menurut jenis dan ukurannya. Setelah selesai memilah-milah ikan, kemudian ikan-ikan tersebut ditimbang dan dicatat dalam pembukuan lengkap dengan jumlah dan harganya.

Setelah selsai penimbangan, pembayaran akan dilakukan saat itu juga, dengan taksiran harga dilakukan secara sefihak oleh "Bos" pedagang pengumpul. Uang tunai akan diterima nelayan setelah terlebih dahulu dikurangi dengan seluruh biaya melaut. Bagi nelayan yang masih memiliki sangkutan hutang dengan "Bos” juga akan dikurangi dengan cicilan hutang. Kalau nasib sedang untung, nelayan masih bisa pulang dengan membawa uang. Tetapi bagi yang tidak beruntung, apa lagi masih memiliki sangkutan hutang, terpaksa nelayan pulang dengan tangan hampa. Berdasarkan hasil pengamatan di PPI Dusun Keramat saat penimbangan ikan, pemotongan-pemotongan cicilan 
hutang ini dilakukan tanpa melalui persetujuan pihak nelayan.

Suatu pemandangan yang lazim disaksikan di PPI, dengan hasil tangkap ikan yang tergolong banyak nelayan berwajah tampak sumringah saat mendaratkan ikannya, wajahnya ceria, kata-katanya diiringi dengan menebar senyum dan tawa, tetapi begitu "Bos" mulai menghitung antara hutang dan perolehan hari itu, suasana ceria penuh canda tibatiba berubah diam membisu, tertegun, muram, lemas, kecewa, raut mukanya masam, karena yang didapat tidak sesuai dengan yang diharapkan. Suasana seperti itu dialami oleh salah seorang nelayan. Pagi itu ia membawa hasil tangkapan yang lumayan banyak setelah ditimbang kemudian ditentukan harganya Rp 350.000,-. Tanpa meminta pertimbangan nelayan pemilik ikan, "Bos" memotong sejumlah Rp 300.000,- untuk mencicil hutangnya. Dengan penuh rasa kecewa yang dipendamnya, nelayan itu diam membisu, berdiri tertegun, dan hanya bisa menerima keadaan dengan sikap pasrah.

Ikan-ikan besar yang sudah terkumpul di TPI, kemudian dimasukkan kedalam box-box streoform dan dimasukkan es, di tutup rapat dengan lak ban. Ikan-ikan ini siap didistribusikan kepada rumahrumah makan, restauran, hotel, yang ada di Lampung dan kalau masih tersisa akan dikumpulkan disimpan difreser. Setelah terkumpul banyak akan disetor kepada pedagang pengumpul besar di Jakarta. Jenis ikan-ikan kecil seperti kembung, tembang, selar, kuniran, akan diambil oleh para wanita pedagang keliling ikan (papalele) yang di PPI Keramat jumlahnya mencapai 20 orang. Jumlah dan jenis ikan yang diambil oleh setiap papalele dicatat dan ditentukan harganya oleh "Bos" penampung ikan. Harga ikan-ikan konsumsi rumah tangga itu berada pada kisaran antara Rp 15.000,- - Rp 20.000,-, tergantung jenisnya. Ikan kembung misalnya, per kg Rp 15.000, cumi-cumi Rp 18.000 per kg, kuniran Rp 15.000 , per kg, dan tembang Rp 10.000,- per kg. Pembayarannya akan dilakukan kepada "Bos" setelah semua ikan laku terjual. Oleh papalele, ikan itu dijual kepada konsumen langsung dengan cara dijajakan keliling dari rumah-ke rumah dan dari pematang kebun ke kebun. Ikan kembung sebanyak 1 kg itu kemudian dibungkus menjadi 3 plastik kresek, dan dijual Rp 10.000 per plastik. Rata-rata kemampuan papalele hanya mampu mengangkat 10 - 15 kg ikan untuk dijajakan. Kalau nasib sedang baik, hari itu juga seluruh dagangan ikan laku terjual. Pembayaran ikan bisa disetor hari itu juga, dan keuntungan sudah didapat. Bila nasib tidak baik, masih banyak dagangan yang tersisa, terpaksa harus diawetkan dengan memberi es atau dibuat ikan asin, yang harganya lebih murah. Hal ini bisa berakibat, setoran tidak tertutup, dan usaha dagangnya merugi. Hari-hari berikutnya, ada perasaan malu untuk mengambil ikan lagi kepada "Bos".

Kegagalan usaha hampir selalu membayangi dalam hidupnya, sebab kegagalan menjual ikan akan berakibat semakin dalam nelayan terjerat hutang pada “Bos” penampung ikan. Demikian halnya dengan nelayan tangkap itu sendiri, kegagalan melakukan penangkapan, akan berarti menelan kerugian materi yang tidak sedikit, dan itu akan membebani nelayan karena modal melautnya diperoleh dari pinjaman. Kendatipun demikian wanita nelayan Dusun Keramat masih beruntung, karena ada peluang usaha menjadi pedagang keliling (papalele). Pada wanita nelayan di Dusun Rimau kesempatan kerja itu tidak diperolehnya, karena tempat tinggal mereka berada di sebuah pulau yang sangat terbatas sarana transportasinya. (Wawancara dengan Ibu Sri, Papalele di Dusun Keramat 27 April 2015).

Perlu diketahui bahwa transaksi jual beli yang dilakukan di PPI Dusun Keramat tidak dilakukan dengan lelang, tetapi dibeli dengan penentuan harga secara sepihak oleh "Bos" penampung ikan. Praktis keberadaan sarana PPI di Dusun Keramat sesungguhnya hanya memfasilitasi "Bos" penampung ikan, untuk mempermudah usaha bisnisnya, dan bukan untuk mempermudah dan mengoptimalkan petugas pemerintah dalam memberikan pelayanan kepada masyarakat nelayan. Menghadapi keadaan seperti itu, tampaknya petugas aparat pemerintah terkait tidak dapat berbuat banyak, untuk membenahi fungsi yang sebenarnya dari keberadaan PPI tersebut.

Dari hasil pengamatan aktivitas transaksi jual beli dan penimbangan ikan di PPI Dusun Keramat, yang diperkuat dengan informasi yang disampaikan nelayan, serta informasi dari pedagang pengumpul di PPI Dusun Keramat, mengatakan bahwa keberadaan ikan-ikan pelagis di perairan pantai Kabupaten Lampung Selatan sudah mengalami penurunan, karena banyaknya kapal bagan congkel beroperasi di perairan Selat Sunda. Dahulu tahuntahun 1980-an, ikan kembung, tembang, belanak, lemuru, cumi-cumi, ikan teri, mudah sekali di dapat dengan menggunakan pancing atau bagan tancap. Dalam satu kali melaut, bagan tancap bisa menghasilkan sekitar 50 bakul (candong) ikan teri per bakul $10 \mathrm{~kg}$. Orang mancing dalam sekali melaut bisa memperoleh $20 \mathrm{~kg}$ ikan kembung. Sekarang bagan tancap sudah sangat jarang, kalau ada diolah sendiri sebagai bahan baku idustri pengolahan ikan asin. Dalam satu kali melaut hanya dapat sekitar 5 kg-10 kg ikan teri. Rata-rata per hari ikan yang didaratkan di PPI Dusun Keramat dari sejumlah 78 anak buah "Bos" yang terdiri dari 50 ABK mengoperasikan 2 unit kapal bagan congkel, dan selebihnya nelayan mancingan hanya mampu mendaratkan ikan berkisar antara $50 \mathrm{~kg}$ - $75 \mathrm{~kg}$ ikan komersial, dan ikan non komersial seperti ikan kembung, tembang, kuniran, tude, sekitar $150 \mathrm{~kg}-$ $200 \mathrm{~kg}$. Angka ini mengalami penurunan cukup jauh di banding 10 tahun yang lalu (2000), masih bisa mencapai 300 kg, bahkan kadang bisa 500 kg. Hasil tangkapan pancingan perahu katir kini rata-rata 
hanya mencapai sekitar 5 kg - 7 kg ikan kembung sekali melaut, dan itu tidak setiap hari dapat. (Wawancara dengan Ruslan 25 April 2015) Kendatipun demikian, nelayan masih merasa bahwa ikan di perairan Selat Sunda masih banyak, terbukti banyak nelayan yang berdatangan mencari ikan di perairan ini.

Rendahnya mutu kualitas SDM nelayan, teknologi alat tangkap yang sederhana, terbatasnya modal, tidak adanya lembaga keuangan formal, tidak dikuasainya informasi pasar, kerusakan lingkungan perairan kesemuanya satu dengan yang lain saling terkait, yang pada ujungnya bermuara pada rendahnya tingkat pendapatan nelayan. Seluruh hasil tangkapan nelayan hanya digunakan untuk memenuhi kebutuhan subsistensinya, bahkan dengan resiko kegagalan dalam penangkapan dan ketidakpastian harga pasar sering menyeret nelayan terbelit hutang kepada "Bos" yang merangkap sebagai pedagang pengumpul ikan. Tidak tersisa sedikit pun untuk dapat disisihkan untuk diinvestasikan dalam menambah ataupun memperbaiki teknologi alat tangkap yang dapat meningkatkan hasil tangkapnya. Seandainya mereka memiliki tingkat pendidikan formal dan keterampilan yang lebih tinggi, mereka dapat keluar dari kegiatan kenelayanan dan memasuki dunia kerja yang lain yang dapat meningkatkan taraf hidup mereka, tetapi di sinilah masalah umumnya yang dihadapi nelayan kecil, semua persyaratan itu tidak dimilikinya (Soemardjan; 1980, 5) Untuk masyarakat nelayan P. Rimau Balak kesempatan kerja di luar sektor perikanan itu sangat terbuka lebar, mengingat wilayah Kabupaten Lampung Selatan khususnya daerah sekitar Pelabuhan Bakauheni merupakan wilayah yang sedang mengalami pertumbuhan ekonomi yang pesat. Dengan segala keterbatasan yang dimilikinya, kesempatan itu tidak dapat diraihnya.

Upaya untuk meningkatkan pendapatan nelayan sudah dilakukan melalui implementasi program Inka Mina seribu kapal tahun 2013. Nelayan Dusun Keramat dan Dusun Rimau mendapat satu unit kapal lengkap dengan mesin dan alat tangkapnya yang siap untuk dioperasikan. Kapal tersebut berbobot 30 GT dengan kemampuan jelajah mampu mengarungi wilayah perairan Zona Ekonomi Exsklusif (ZEE). Nilai total kapal bantuan ini sejumlah 1,5 milyard rupiah. Kapal bantuan ini dikelola oleh sejumlah 10 orang yang tergabung dalam satu kelompok. Anggota-anggota tersebut justru bukan berasal dari para nelayan kecil, tetapi dari sejumlah petugas yang ada di PPI Dusun Keramat, juragan penampung ikan di PPI Keramat, dan para perangkat desa yang salah satunya adalah Nurjaman selaku Kepala Dusun Rimau.

Bantuan kapal ini menimbulkan kecemburuan sosial dikalangan masyarakat nelayan, karena yang memperoleh bantuan justru bukan nelayan kecil. Dengan kata lain bantuan tersebut tidak sampai pada sasarannya. Menurut penuturan Nurjaman, seluruh anggota kelompok dan pengurusnya sepakat kalau kapal ini tidak diberikan ke nelayan kecil, sebab justru akan membebani nelayan. Biarlah tokoh-tokoh masyarakat ini yang menanggung bebannya. Kapal ikan ini tidak efisien, karena boros bahan bakarnya. Pernah dicoba melaut, dalam hitungan tidak sampai 1 jam sudah menghabiskan bahan bakar 40 liter solar. Jaring yang digunakan untuk menangkap ikan molos. Antara bibir dinding lambung kapal dan permukaan air laut terlalu tinggi, sehingga ikan jatuh ke laut sebelum sampai di lantai/dek kapal. Hingga sekarang kapal tersebut mangkrak sandar di Dermaga PPI Dusun Keramat. (Wawancara dengan Nurjaman, 25 April 2015)

Program tersebut sangat disesalkan masyarakat, seandainya uang sebanyak itu dibelikan perahu bagan congkel dengan harga Rp 100 juta per unit, akan diperoleh 15 unit kapal bagan congkel ukuran kecil, dengan kapasitas 10-15 orang per unit, maka minimal orang satu kampung ini bisa terlibat dalam aktivitas penangkapan ikan. Sejumlah wanita pedagang ikan (papalele), serta sejumlah pekerja wanita dapat terserab dalam industri pengolahan ikan. Akibatnya program ini bukan saja gagal mengentaskan kemiskinan nelayan, yang terjadi malah justru membebani nelayan harus merawat dan menunggui kapal yang mangkrak. Kalau demikian, bagaimana mereka bisa melangsungkan kehidupan di tengah pulau kecil yang “terisolir” ini.

\section{Strategi Bertahan Hidup Nelayan}

Nelayan dalam menjalankan aktivitasnya dihadapkan dengan ketidakpastian lingkungan yang mengitarinya. Lingkungan di sini meliputi lingkungan fisik maupun lingkungan sosial yang salah satunya adalah ketidak pastian pasar. Pada hal ikan sebagai hasil tangkapnya memiliki sifat mudah rusak dan cepat membusuk. Karakteristik yang lain adalah bahwa dalam menjalankan aktivitasnya nelayan membutuhkan modal usaha yang tidak sedikit yang harus selalu tersedia disaat nelayan hendak melaut. Uang juga dibutuhkan sewaktuwaktu untuk mengganti atau memperbaiki sarana dan alat tangkap. Sementara modal itu tidak dimilikinya, mereka juga tidak memiliki akses kepada lembagalembaga keuangan formal. Karena itu menjalin relasi sosial dengan sesama warga dusun dan para pemilik modal terutama para pedagang penampung ikan menjadi solusi untuk berbagi resiko dalam menghadapi ketidak pastian usaha agar dapat menjamin kebutuhan subsistensinya.

Seperti halnya pada masyarakat pedesaan yang lain, masyarakat nelayan P. Rimau Balak yang mengelompok di beberapa kampung, masing-masing membentuk kelompok komunitas nelayan yang ditandai oleh, ikatan tempat tinggal yang sama, hubungan diantara warga bersifat personal dan intim, adanya ikatan rasa solidaritas sosial yang tinggi, sehingga melahirkan sentimen antar warga 
komunitas yang tinggi pula. Tipologi masyarakat yang demikian lazim disebut sebagai masyarakat paguyuban yang didasarkan pada ikatan tempat tinggal yang sama (gemeinschaft of place) (Syahrial Syarbaini Rusdianta, 2009, 44). Hubungan yang harmonis tersebut selalu dijaga melalui berbagai aktivitas tolong menolong, seperti gotong royong dalam menggarap kebun, memperbaiki alat tangkap, memperbaiki rumah, dan dalam berbagai keperluan lainnya. Saling berbagi diantara warga, juga menjadi ciri lain dari warga desa. Hal ini tampak misalnya saat mereka bekerja di kebun, diantara wanita-wanita saling menolong dalam merawat tanaman di kebun. Mereka juga saling berbagi bekal makanan yang dibawa dari rumah masing-masing. Demikian juga dalam memenuhi kebutuhan sayur mayur untuk memenuhi kebutuhan sehari-hari, bagi yang tanaman sayurnya belum siap dipetik, mungkin juga hari itu tidak bisa ke kebun karena suatu hal, seseorang bisa meminta kepada tetangganya.

Saling berbagi juga dilakukan saat menjalankan aktivitas melaut. Hal ini tampak seperti, saling berbagi bekal makanan saat di tengah laut. Saling memberi tumpangan untuk aktivitas memancing karena seseorang mungkin tidak cukup bahan bakar hari itu untuk melaut, atau mungkin mesin perahunya sedang mengalami kerusakan, sehingga cukup menumpang pada perahu tetangga. Saling berbagi hasil tangkapan pada saat seorang nelayan mendapatkan hasil tangkap lebih, walau hanya sekedar untuk lauk pauk.

Meminjam dari Cliffort Geertz (1976, 84105) tentang kemiskinan di pedesaan Jawa yang menyebutkan bahwa jaringan sosial yang tumbuh di kalangan mereka, seperti saling tolong menolong dengan cara bergotong royong dalam mengolah lahan pertanian, membuat kerajinan tangan, atau aktivitas lain seperti memperbaiki rumah, lebih dimaksudkan sebagai pemerataan kemiskinan (share poverty). Dalam kesimpulan Geertz apapun yang dikuasai orang miskin, termasuk institusi sosial selalu berputar dalam mekanisme yang involutif, yang menjebak mereka sendiri untuk tetap dan terus berada di dalam kubangan kemiskinan.

Selain menjalin relasi sosial yang bersifat horisontal tersebut, nelayan P. Rimau Balak juga menjalin relasi sosial dengan kelompok masyarakat yang memiliki status sosial ekonomi yang lebih tinggi, antara lain dengan para pemilik tanah $\mathrm{P}$. Rimau Balak yang tinggal di Jakarta dan "Lampung Daratan”. Para pemilik tanah ini mempercayakan orang lain untuk mengawasi dan mengontrol penguasaan/pemilikan tanahnya di P. Rimau Balak. Kepada merekalah masyarakat nelayan P. Rimau Balak meminta izin untuk sekedar membangun tapak rumah tinggal dan menggarap lahannya dengan sistem sewa. Sistem sewa tanah ini tidak diperhitungkan secara komersial, tetapi hanya membayar sekedarnya. Semua lahan garapan dikenakan tarif yang sama tanpa memperhitungkan luas sempitnya garapan, yakni sebesar Rp 50.000,per tahun.

Kebun-kebun garapan ini dikerjakan oleh kaum wanita. Luas garapannya antara 500 m2 - 1000 mr2. Jenis tanaman yang di tanam, antara lain tanaman pangan seperti, jagung, ubi jalar, dan singkong. Tanaman sayur-sayuran seperti terung, tomat, cabe, kacang panjang, kecipir, dan katu. Tanaman lainnya berupa tanaman buah-buahan seperti sirsat, jambu, pisang, dan nangka. Usaha tani ini merupakan usaha sampingan, dilakukan secara kecil-kecilan, dan hasilnya hanya sekedar untuk dapat memenuhi kebutuhan pangan sehari-hari. Diantara tanam-tanaman tersebut, tanaman jagung yang dapat dijual. Dalam areal seluas $500 \mathrm{~m} 2$ bisa menghasilkan sekitar 5 karung jagung dalam kondisi belum jadi pipilan. Harga per karung Rp 90.000,-. Dengan demikian kalau seseorang mengusahakan lahannya hanya seluas $500 \mathrm{~m} 2$ akan diperoleh sebesar Rp 450.000,- sekali panen. Dalam setahun dapat dipanern 3 kali, dan yang bagus hasilnya hanya panen yang pertama dan yang ke dua. Tanaman yang ke tiga biasanya hasilnya sedikit, atau bahkan gagal panen karena kekeringan. Jenis tanaman jagung yang ditanam ini merupakan jenis jagung yang dikembangkan di Lampung untuk dipasok sebagai bahan baku pabrik yang diolah menjadi pakan ternak. Dari hasil panen jagung tersebut biasanya masyarakat langsung digunakan untuk membeli beras.

Hasil panen sebesar itu, masih harus dikurangi dengan harga bibit, pupuk dan obatobatan. Hasil bersih kurang lebih Rp 350.000,dalam satu kali panen. Bila orang mengusahakan seluas 1000 m2, hasilnya sekitar Rp 700.000,- dalam sekali panen. Bila diambil rata-rata petani mengusahakan $750 \mathrm{~m} 2$, hasil bersih sekitar Rp 525.000,-. Bila dikonversi dengan harga beras Rp 9000,- per kg, maka akan diperoleh sekitar 58 kg beras. Bila dihitung 3 kali panen, hanya setara dengan $174 \mathrm{~kg}$ beras per tahun. Angka ini masih jauh di bawah garis kemiskinan untuk masyarakat pedesaan sebesar $240 \mathrm{~kg}$ per kapita per tahun (Sayogyo, 1978;3)

Sekalipun demikian, usaha tani ini juga dihadapkan dengan resiko kegagalan panen yang tinggi. Penyebabnya berbagai hama sering menyerang tanaman penduduk; antara lain babi hutan, belalang, wereng, tikus, dan terakhir sering menghadapi serbuan kawanan monyet. Informasi yang disampaikan Nurjaman, serangan monyet terhadap ladang penduduk berlangsung secara masive. Dalam waktu hitungan satu malam saja, seluruh ladang jagung yang mulai berbuah, ludes diserang kawanan monyet. Peristiwa gagal panen ini sudah terlalu sering menimpa masyarakat P. Rimau Balak. Kawanan monyet ini menakutkan ibu-ibu yang sedang bekerja di kebun, sebab sewaktu-waktu secara mendadak siap menyerbu orang yang mengetahuinya. 
Upaya mengendalikan serangan monyet ini sudah dilakukan dengan memasang jerat, tetapi tidak juga berhasil. Hewan ini termasuk jenis binatang yang cerdik, selalu dapat menghindar dari jeratan. Ancaman serangan hewan monyet ini terjadi karena berlangsungnya migrasi kawanan monyet, dari daratan Lampung menuju ke wilayah kepulauan. Informasi yang disampaikan oleh Nurjaman menyebutkan bahwa kawanan monyet tersebut menyeberang perairan Selat Sunda diwaktu malam hari. Suatu hari ia sendiri pernah menyaksikan segerombolan monyet yang jumlahnya mencapai puluhan tengah menyeberang dari daratan Lampung menuju P. Rimau Balak. Dipukulnya salah satu rombonngan monyet yang berada di paling belakang dengan menggunakan dayung. Satu ekor berhasil ditangkap, selebihnya lolos dan masuk di ladangladang penduduk. Penyebab terjadinya migrasi hewan monyet tersebut karena rusaknya habitat dengan hilangnya tutupan tanaman keras perbukitan di Lampung (Wawancara dengan Nurjaman 25 April 2015). Kasus-kasus meluasnya serangan hama yang dihadapi masyarakat P. Rimau Balak ini menunjukkan betapa tinnginya resiko kegagalan dalam usaha tani.

Selain usaha tani, untuk memenuhi kebutuhan subsistensinya, masyarakat juga menjalin relasi dengan para pemilik modal yang tinggal di wilayah daratan Lampung, terutama para pemilik ternak kambing. Dengan para pemilik ternak ini, masyarakat meminta sepasang induk kambing untuk dipelihara. Usaha bagi hasil dengan memelihara ternak milik orang lain ini lazim disebut dengan sistem gaduh. Perhitungannya, kelak kalau indukan kambing sudah beranak, anaknya tersebut akan dibagi dua. Satu bagian untuk pemilik, dan satu bagian untuk si pemelihara.

Usaha ternak secara kecil-kecilan dengan sistem gaduh ini dilakukan hampir oleh seluruh penduduk Dusun P. Rimau Balak. Daerah ini tampaknya memang sangat potensial untuk pengembangan ternak kambing. Di P. Rimau Balak, masih ditemukan banyak semak belukar dan tumbuhan pakan ternak di kebun-kebun penduduk, seperti tanaman lamtoro gung, kleresedeae, daun nangka, dan rumput pakan ternak. Usaha ini dilakukan oleh kaum wanita. Selepas menggarap kebun, sekitar jam 10.00 pagi, wanita-wanita mencari pakan ternak dari kebun mereka masingmasing. Pekerjaan ini lazim disebut "ngramban". Setelah pakan terkumpul, kemudian di bawa pulang. Selain mencari pakan ternak dari tumbuhan tanaman perdu di kebun, pada sore harinya sekitar jam 16.00 sore, biasanya ibu-ibu juga mencari rumput semaksemak belukar dan lahan-lahan terbuka yang ada. Pekerjaan ini lazim disebut "ngarit”

Pemeliharaan hewan ternak bagi masyarakat dinilai sangat berharga. Hewan ternak merupakan tabungan satu-satunya yang sewaktu-waktu membutuhkan akan dijual. Harga kambing ukuran besar di atas bobot $40 \mathrm{~kg}$ Rp 1800.000,-, ukuran sedang di atas bobot $30 \mathrm{~kg}$ Rp 1.500.000,-. Biasanya hasil ternak kambing akan dijual pada saat menjelang Hari Raya Idul Fitri atau Hari Raya Idul Adha. Uang dari hasil menjual hewan ternak tersebut akan digunakan untuk membeli pakaian dan mempersiapkan kue-kue makanan di hari raya. Sedikit uang yang masih tersisa, akan digunakan untuk rekreasi naik kapal Fery Roro ke Jakarta, walau hanya untuk sekedar melihat-lihat Mol. Sambil sejenak melupakan kampung halamannya (Wawancara dengan wanita pekebun Di Dusun Rimau Balak, 27 April 2015).

Optimalisasi pemanfaatan tenaga kerja keluarga, tidak hanya berhenti sampai disitu. Tenaga kerja anak-anak juga dilibatkan untuk mencari nafkah. Usia rata-rata anak terlibat dalam pekerjaan dikebun dan melaut biasanya di atas 10 tahun. Pekerjaan yang dilakukan bagi anak laki-laki antara lain membantu ayahnya mencari ikan dengan memancing, mencari ikan sendiri di tepi-tepi pantai dan hutan mangrove dengan memancing, dan bagi anak perempuan membantu ibunya bekerja dikebun, serta mencari rumput. Hasil pencarian anak-anak ini diserahkan kepada orang tua. Bagi anak-anak yang masih sekolah, sebagian digunakan untuk uang jajan.

Dalam menjalankan aktivitasnya, nelayan katir membutuhkan biaya operasional sebesar Rp 30.000,- dalam sekali melaut. Karena itu ketersediaan uang cash pada setiap keluarga nelayan merupakan kebutuhan yang tidak bisa ditunda. Kendatipun demikian, uang sebesar itu tidak selalu tersedia. Sementara tidak ada lembaga keuangan formal baik dalam bentuk koperasi nelayan, keuangan mikro, perbankan, bahkan pelepas uang (rentenir) sekalipun yang mau beroperasi di P. Rimau Balak. "Keterisolasian” wilayah, letak permukiman penduduk yang terpencar-pencar, terbatasnya sarana transportasi, maupun jumlah penduduk yang menurut kalkulasi ekonomi mungkin tidak memenuhi skala usaha, tampaknya merupakan pertimbangan ketidakhadiran lembaga keuangan tersebut.

Dalam kondisi demikian, hanya ada dua pilihan, yakni meminjam kepada tetangga dekat, teman, atau keluarga yang tinggal di Dusun Rimau. Pilihan ke dua meminjam kepada "Bos” penampung ikan di Dusun Keramat. Pilihan pertama dilakukan ketika tidak sempat datang ke "Bos", atau sudah banyak hutangnya kepada "Bos" dan sudah lama tidak menghadap "Bos" untuk mencicil utangnya. Hal ini bisa terjadi karena kebutuhan rumah tangganya yang memang mendesak untuk dibiayai lebih dahulu dengan menunda membayar hutangnya. Bisa juga terjadi karena sudah berkali-kali melaut tidak mendapatkan hasil. Jika pilihan pertama tidak berhasil, maka hanya tinggal ada pilihan memberanikan diri menghadap ke "Bos" untuk meminta pinjaman lagi, atau memutuskan untuk tidak pergi melaut dengan menggunakan perahunya 
sendiri. Dalam situasi demikian biasanya orang akan berusaha mencari tumpangan kepada nelayan tetangga, atau teman dekat untuk sekedar ikaut memancing. Sudah menjadi kebiasaan bila nelayan penumpang ini mendapat hasil tangkapan, maka akan memberikan sebagian hasilnya kepada pemilik perahu sebagai ucapan tanda terima kasih. Besarnya pemberian tidak ditentukan, tergantung keiklasan.

Kebutuhan pinjaman uang tunai kepada "Bos" penampung ikan tidak hanya terbatas pada ikatan kerja kenelayanan, tetapi sering kali meluas kepada pemenuhan kebutuhan rumah tangga yang lain, seperti membiayai keperluan hajatan keluarga, sunatan, kematian, pesta pernikahan, membiayai orang sakit, dan perbaikan rumah tinggal. Menurut penuturan Sanusi selaku pengurus RT Busung Berah menyatakan hampir seluruh masyarakat di Dusun Rimau dan Dusun Keramat yang tinggal di sekitar PPI, terlibat hutang kepada "Bos" penampung ikan untuk berbagai keperluan.

Bagi pemilik modal, pemberian hutang merupakan salah satu cara mengikat untuk dapat menjamin kelangsungan bisnisnya. Meskipun demikian, bagi seorang "Bos" penampung ikan pemberian pinjaman kepada nelayan bukan berlangsung tanpa resiko. Ruslan sendiri selaku "Bos" penampung ikan di PPI Dusun Keramat menuturkan, diantara 78 orang yang menjadi anak buahnya, 8 orang diantaranya tidak membayar hutang. Orangnya sendiri tidak diketahui lagi dimana keberadaannya. Dari 8 orang tersebut pinjaman uang yang tidak dikembalikan sebesar Rp 30.000.000,(tiga puluh juta rupiah). Sementara itu, bagi nelayan keberadaan pemilik modal yang selalu menyediakan jasa baiknya merupakan gantungan hidup satusatunya bagi kelangsungan hidup nelayan. Lebih dari itu "Bos" dimata nelayan merupakan dewa penyelamat. Corak hubungan seperti itu telah melahirkan pola hubungan antara Sang pelindung (patron) dengan nelayan sebagai pihak yang dilindungi (client). Dalam hubungan yang demikian ditandai oleh adanya unsur”hutang budi”.

Adanya ikatan emosional antara sang patron dengan client inilah yang membedakan dengan hubungan lain yang bersifat kontraktual. Hubungan patron-client akan tetap langgeng selama patron masih mampu dan bersedia memenuhi kebutuhan subsistensi keluarga nelayan. Dalam situasi tidak adanya alternatif pekerjaan lain di luar kegiatan kenelayanan yang lebih menjanjikan, serta tidak adanya intervensi ekonomi dari pihak luar, maka hubungan patron-client pada masyarakat nelayan $\mathrm{P}$. Rimau Balak akan tetap langgeng.

Strategi lain yang dilakukan oleh masyarakat nelayan P. Rimau Balak dalam memenuhi kebutuhan subsistensinya adalah dengan melakukan penghematan pengeluaran. Meminjam istilah yang diberikan Scott (1976) "mengencangkan ikat pinggang”. Misalnya, keluarga nelayan tidak mengkonsumsi ikan hasil tangkapannya, tetapi akan menjualnya yang kemudian akan dibelikan beras. Lauk pauk sehari-hari cukup dengan mengkonsumsi tempe, super mie, atau sayur-sayuran yang dipetik dari kebun. Nelayan juga tidak pernah mengkonsumsi daging, sekalipun mereka memiliki ternak kambing, tetapi lebih suka memilih untuk menjualnya yang kemudian akan dibelanjakan barang-barang kebutuhan rumah tangga yang dirasa paling diperlukan. Sikap seperti ini bukan berarti nelayan tidak tau kalau ikan dan daging itu mengandung protein dan gizi yang tinggi. Bukan pula karena tidak mengerti tentang kesehatan, tetapi pilihan ini diambil dengan pertimbangan kalau ikan dan daging itu dikonsumsi sendiri, mungkin hanya akan mengenyangkan dan memuaskan selera akan kelezatan sesaat, tetapi akan mengurbankan kebutuhan dasar rumah tangga yang lain dalam jangka panjang yang justru akan dapat mengancam bagi kelangsungan hidup nelayan. Meminjam istilah Scott (1976) strategi inilah yang disebut sebagai “strategi subsistensi” bagi petani miskin.

Menurut pengakuan ibu-ibu yang tergabung dalam Focus Group Discutions (FGD), menyatakan bahwa masyarakat nelayan di Dusun Rimau hanya setahun sekali mengkonsumsi daging, yakni pada saat Hari Raya Idul Adha. Demikian juga jarang mengkonsumsi ikan, kecuali ikan hasil tangkap yang tidak laku dijual karena cacat. Demikian juga hanya sekali dalam setahun membeli pakaian baru untuk merayakan Hari Raya Idul Fitri (Wawancara dengan ibu-ibu nelayan melalui FGD di Dusun Rimau, 25 April 2015)

\section{KESIMPULAN}

Bertolak dari uraian sebelumnya, maka dapat diketahui bahwa untuk dapat memenuhi kebutuhan subsistensinya, masyarakat nelayan di P. Rimau Balak telah melakukan berbagai strategi, antara lain dengan memanfaatkan kelembagaan setempat yang masih cukup kuat seperti gotong royong, ikatan kekerabatan, hubungan ketetanggaan, rasa solidaritas yang tinggi diantara sesama warga, telah melahirkan sikap tenggang rasa yang muncul dalam bentuk saling berbagi diantara warga nelayan P. Rimau Balak. Hubungan sosial ini merupakan salah satu mekanisme strategi bertahan hidup pada kelompok masyarakat nelayan miskin.

Secara fertikal masyaraka nelayan P. Rimau Balak juga menjalin hubungan baik dengan pihakpihak yang menguasai sumber daya ekonomi, seperti orang-orang yang dipercaya para pemilik tanah untuk mengontrol tanah yang dikuasainya dan "Bos" pemilik modal di PPI Dusun Keramat yang merangkap sebagai pedagang pengumpul ikan. Hubungan sosial fertikal diantara sebagian besar masyarakat yang memiliki keterbatasan dalam mengakses sumber daya ekonomi di satu pihak dengan sekelompok kecil orang yang menguasai dan mengontrol sumber daya ekonomi yang ada, telah 
melahirkan corak hubungan patron - client. Orang luar (etik) melihat bahwa hubungan tersebut sangat kental dengan tindakan eksploitatif dari pihak yang kuat terhadap yang lemah. Hubungan semacam inilah yang membuat nelayan terperangkap dalam lembah kemiskinan, karena jeratan hutang. Sementara itu, bagi nelayan sendiri ditengah keterbatasan akses sumber daya yang dimiliki, serta ketiadaan bantuan dari luar yang memungkinkan mereka untuk keluar dari lingkaran kemiskinan tersebut, maka keberadaan para pemilik modal dimata nelayan telah dianggap sebagai pihak yang mampu menjamin kebutuhan subsistensinya.

Strategi lain yang dilakukan oleh masyarakat nelayan dalam memenuhi kebutuhan subsistensinya yakni melakukan optimalisasi pemanfaatan sumber daya yang ada, atau strategi nafkah ganda. Strategi ini dilakukan dengan mengerahkan seluruh tenaga kerja keluarga yang ada, seberapa pun kontribusinya dalam pemenuhan kebutuhan dasar rumah tangga nelayan. Pada saat yang sama, rendahnya tingkat pendapatan nelayan dan ketidakpastian usaha yang dijalaninya, telah memaksa nelayan harus melakukan "strategi subsistensi" dengan menghemat pengeluaran dan menurunkan kuantitas dan kualitas menu makan agar dapat memperpanjang kelangsungan hidupnya.

Mengingat kemiskinan yang dihadapi masyarakat nelayan P. Rimau Balak bersifat multidimensi, maka upaya penanganannya pun harus bersifat menyeluruh dan tidak sekedar tambal sulam. Penanganan yang bersifat parsial, justru malah akan semakin membebani masyarakat. Kasus kegagalan program bantuan Kapal Seribu Inka Mina pada masyarakat nelayan Dusun Keramat dan Dusun Rimau merupakan salah satu contoh akan hal itu. Kasus ini juga telah menguatkan suatu teori bahwa ketiadaan cadangan modal pada kelompok miskin, membuat mereka tidak responsif terhadap inovasi teknologi baru, sebab bila terjadi kegagalan dampaknya akan fatal, yakni bisa menenggelamkan ekonomi seluruh keluarga nelayan. Menurut Scott (1981, 3 - 8) praktek budaya “mencari aman” yang bisa tetap dipegang untuk menjalankan kehidupan sehari-hari. Kehidupan orang miskin ibarat "orang yang selamanya berdiri terendam dalam air sampai ke leher, sehingga ombak yang kecil sekalipun sudah cukup untuk menenggelamkannya”.

Menurut Mubyarto (1995; 160) untuk mengangkat nelayan miskin dari lembah kemiskinan ada beberapa hal yang harus dilakukan, antara lain peningkatan kualitas sumber daya manusia, pengembangan peluang kerja, dan berusaha, dan penguatan lembaga kelompok masyarakat miskin. Solusi tersebut tampaknya bisa juga digunakan untuk mengatasi kemiskinan masyarakat nelayan P. Rimau Balak. 


\section{Daftar Pustaka}

Acheson, James M. Anthropology of Fishing, dalam Annual Review of Anthropology. Annual Review, 1981, PP 275 - 307.

Arif Satria, 2002. Pengantar Sosiologi Masyarakat Pesisir, PT. Pustaka Cidesindo, Jakarta.

Bagong Suyanto \& Karanji, 2005. Kemiskinan dan Kesenjangan Sosial: Ketika Pembangunan Tak Berpihak Kepada Rakyat Miskin. Universitas Erlangga, Surabaya.

Biro Pusat Statistik (2010), Sensus Penduduk Indonesia Tahun 2010, BPS. Jakarta,

Cliffort Geertz, 1963, Agricultural Involution: The Process of Ecological Change in Indonesian. University of California Press. Berkeley.

Karl D. Jackson \& Lucian W. Pye, eds 1978. The Implication of Structure and Culture in Indonesia, dalam "Political Power and Comunications in Indonesia”, Mexico Press.

Kusnadi, 2002. Adaptasi dan Jaringan Sosial, Humaniora Utama Press. Bandung.

Mubyarto, 1984. Nelayan dan Kemiskinan, Rajawali Press, Jakarta.

, 1995. Strategi Pembangunan Ekonomi Yang Berkeadilan dalam Awan Setya Dewanta, Kemiskinan dan Kesenjangan di Indonesia. Penerbit: Aditya Media, Yogyakarta.

Sayogyo, 1978. Lapisan Paling Lemah Masyarakat Pedesaan Jawa, Prisma 3: 3 - 14, LP3ES, Jakarta.
1977. Garis Kemiskinan dan Kebutuhan Minimum Pangan, LPSP, IPB. Bogor.

Scott, James C. 1981. Moral Ekonomi Petani: Pergolakan dan Subsistensi di Asia Tenggara”, Yayasan Obor Indonesia, Jakarta. 1976. The Moral Economy of the Peasant, New Aven, Yale University Press.

Supriharyono, 2000. Pelestarian Dan Pengelolaan Sumber Daya Alam di Wilayah Pesisir Tropis, Gramedia. Jakarta.

Yahya Muhaimin, 1980. Beberapa Segi Birokrasi di Indonesia, Prisma 10. LP3ES. Jakarta.

Http:repository/ipb/ac.id/handle/123456789/70324. Diakses 22 Juli 2015.

http://fdwiagungwidodo.wordpress.com. Diakses 4 Agustus 2015.

Wawancara dengan Wanita Nelayan di Dusun Rimau melelui Focus Group Discutions (FGD) 25 April 2015.

Wawancara dengan Bapak Nurjaman Kepala Dusun Rimau, di Dusun Rimau 25 April 2015.

Wawancara dengan Bapak Sanusi Ketua Rt 1 Dusun Rimau, 24 April 2015.

Wawancara dengan Suminto Kepala Dusun, Di Dusun Keramat 24 April 2015

Wawancara dengan Bapak Jajang Kepala UPT Bakauheni, 27 April 2015.

Wawancara dengan Bapak Totok Pedagang Penampung Ikan di Dusun Pegantungan 24 April 2015.

Wawancara dengan Ibu Sri, pedagang keliling ikan (Papalele) di Dusun Keramat, 27 April 2015. 
